\title{
Article \\ Sealing Efficacy of the Original and Third-Party Custom-Made Abutments-Microbiological In Vitro Pilot Study
}

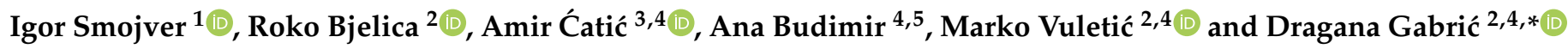 \\ 1 St. Catherine Specialty Hospital, 10000 Zagreb, Croatia; ismojver@gmail.com \\ 2 Department of Oral Surgery, School of Dental Medicine, University of Zagreb, 10000 Zagreb, Croatia; \\ rbjelica@sfzg.hr (R.B.); mvuletic@sfzg.hr (M.V.) \\ 3 Department of Fixed Prosthodontics, School of Dental Medicine, University of Zagreb, 10000 Zagreb, Croatia; \\ catic@sfzg.hr \\ 4 Department of Dental Medicine, University Hospital Centre Zagreb, 10000 Zagreb, Croatia \\ 5 Department of Clinical and Molecular Microbiology, School of Medicine, University of Zagreb, \\ University Hospital Centre Zagreb, 10000 Zagreb, Croatia; abudimir@kbc-zagreb.hr \\ * Correspondence: dgabric@sfzg.hr
}

check for

updates

Citation: Smojver, I.; Bjelica, R.; Ćatić, A.; Budimir, A.; Vuletić, M.; Gabrić, D. Sealing Efficacy of the Original and Third-Party Custom-Made Abutments-Microbiological In Vitro Pilot Study. Materials 2022, 15, 1597. https://doi.org/10.3390/ ma15041597

Academic Editors: Marco Cicciu and Rafael Delgado-Ruiz

Received: 13 January 2022

Accepted: 19 February 2022

Published: 21 February 2022

Publisher's Note: MDPI stays neutral with regard to jurisdictional claims in published maps and institutional affiliations.

Copyright: (C) 2022 by the authors. Licensee MDPI, Basel, Switzerland. This article is an open access article distributed under the terms and conditions of the Creative Commons Attribution (CC BY) license (https:// creativecommons.org/licenses/by/ $4.0 /)$.

\begin{abstract}
Implant-abutment connection (IAC) is a key factor for the long-term success and stability of implant-supported prosthodontic restoration and its surrounding tissues. Misfit between prosthodontic abutment and implant at the IAC leads to technical and biological complications. Two kinds of prosthodontic abutments are currently available on the market: original and third-party abutments. The aim of this pilot study was to test and compare the internal fit (gap) at the implant-abutment interface depending on the abutment fabrication method based on microbial leakage in static conditions and the need for the use of gap sealing material. Two groups of 40 implants were formed on the basis of the type of abutment. In each of the groups of two implant systems, two subgroups of 10 implants were formed. The tested subgroups consisted of 10 implants with sealing material and a negative control subgroups consisting of 10 implants without any sealing material. The test material, GapSeal (Hager and Werken, Duisburg, Germany) was applied in the test subgroups. The implant-abutment assemblies were contaminated with a solution containing Staphylococcus aureus and Candida albicans for 14 days under aerobic conditions. Results showed that there was no statistically significant difference regarding the microbial leakage between the original and third-party custom-made abutments, regardless of the use of sealing material. It can be concluded that the abutment fabrication method has no significant influence on sealing efficacy regarding the bacterial and fungal leakage in static conditions.
\end{abstract}

Keywords: dental implant; dental implant-abutment design; implant-abutment connection; microbial colony count; peri-implantitis

\section{Introduction}

Implant-prosthodontic therapy is an established treatment modality in dental practice that provides high success rates [1]. Implant-abutment connection (IAC) is recognized as a crucial factor for the long-term success and stability of implant-supported prosthodontic restoration and its surrounding tissues, with emphasis on benefits of original abutments [2]. Misfit between such components presents a significant concern because it may lead to mechanical and biological complications [3]. The most common and highly researched biological complication is peri-implantitis, which is influenced by plaque accumulation at the level of the IAC [4]. The presence of a microgap is unavoidable in two-piece implants, and it is precisely this narrow space that makes a small reservoir of microorganisms interfering with the health of the peri-implant tissue [4]. This space is considered to be a critical area in microbial colonization, and also a starting point for peri-implant marginal bone loss [5]. Different implant systems use different designs for the IAC, with 
the main purpose of microleakage prevention and consequential inflammation of periimplant tissues. They can be classified as internal or external, with internal being the most commonly used. The internal IAC can be further divided into clearance-fit (or straight), conical, and mixed [2]. However, possible production imprecision and dynamic masticatory load can result in the aforementioned presence of a microgap and micromotion at the IAC, which directly or indirectly might cause technical damage [2]. Even though there is no evidence of complete prevention of miocrobial infiltration through the IAC, there are constant efforts to achieve a tight connection between prosthodontic abutment and implant fixture [6]. The microgap varies between 10 and $135 \mu \mathrm{m}$ according to different implant systems [6,7]. This is a wide range of values and, moreover, refers to original prosthetic abutments. Two kinds of prosthodontic abutments are currently available on the market for implant restorative procedures: original and third-party abutments [8]. The industry claims that the original parts are better in terms of fit and reduced microleakage [8]. Given the vast possibilities for combinations of variables in implant-prosthodontic rehabilitation, the abutment fabrication method should be carefully evaluated. Regarding these facts, there are materials on the market that are declared to seal the gap at the IAC in order to eliminate microleakage, thus reducing or eliminating biological complications [9]. GapSeal (Hager and Werken, Duisburg, Germany) is such a material, and is based on a highly viscous silicone matrix with thymol. It remains durably viscous and can be removed only by ethanol or by mechanical means. Considering the given information, it should provide long-term protection, avoiding auto- and re-infections by possible microbial accumulation at the IAC [10].

Currently, only a limited number of investigations comparing the leakage of original and third-party abutments with the internal type of IAC are available. Therefore, the purpose of this study was to test and compare the internal fit (gap) at the IAC depending on the abutment fabrication method (original and third-party) based on bacterial and fungal leakage in static conditions. A comparison was performed for both straight and conical types of IAC. Additionally, the antimicrobial efficacy and need for the use of gap sealing material was tested.

The null hypothesis was that the abutment fabrication method would have no influence on the internal fit at the IAC, regardless of the connection type and use of a sealing agent.

\section{Materials and Methods}

\subsection{Study Design}

This microbiological in vitro pilot study was approved by the Ethics Committee of the School of Dental Medicine University of Zagreb (protocol code: 05-PA-30-XII-12/2019 on 5 December 2019) and performed at the laboratory of the Department of Clinical and Molecular Microbiology, University Hospital Centre Zagreb. The microbiological preparation and sampling methodology itself was developed based on recent pilot study by Smojver et al. [9]. The developed protocol has been tested repeatedly, in particular for static in vitro test conditions.

A total of 80 titanium dental implants were used in the study, of which 40 were GC Aadva Standard implants (GCTech.Europe GmbH, Breckerfeld, Germany), with a conical type of connection, and 40 were Zimmer Tapered Screw-Vent implants (Zimmer Biomet Dental, Palm Beach Gardens, FL, USA) with a straight type of connection. The implants were divided into two groups each, regarding the type of prosthetic abutment (A and B).

Group A consisted of 20 GC Aadva Standard implants (GCTech.Europe GmbH, Breckerfeld, Germany) of $4.0 \mathrm{~mm}$ diameter and 20 Zimmer Tapered Screw-Vent implants (Zimmer Biomet Dental, Palm Beach Gardens, FL, USA) of $4.1 \mathrm{~mm}$ diameter, both connected to their respective original factory-made prosthodontic abutments.

Group B consisted of 20 GC Aadva Standard implants of $4.0 \mathrm{~mm}$ diameter and 20 Zimmer Tapered Screw-Vent implants of $4.1 \mathrm{~mm}$ diameter, both connected to respective third-party custom-made prosthodontic abutments. The abutments were designed in 
Exocad Galway 3.0 (Exocad GmbH, Darmstadt, Germany). Computer-aided design (CAD) data were sent to computer-aided manufacturing (CAM) software (Mayka Dental 5.1, PicaSoft, Vierzon, France) and then to a Yenadent DC40 milling machine (Yenadent, Vierzon, France). The abutments were milled from a Colado CAD Ti5 (Ivoclar Vivadent AG, Schaan, Liechtenstein) titanium alloy. In each of the groups (A and B), four subgroups of 10 implants were formed. Ten implants per group were required for the study according to the statistical power analysis. The two tested subgroups consisted of 10 Zimmer and $10 \mathrm{GC}$ implants with sealing material and two negative control subgroups consisted of 10 Zimmer and 10 GC implants without any sealing material. GapSeal gel (Hager and Werken, Duisburg, Germany) was used as a sealant. According to the results obtained in the recent study by Smojver et al. [7], it showed the highest values in microbial leakage prevention, so it was the material of choice in this study. (Figure 1)

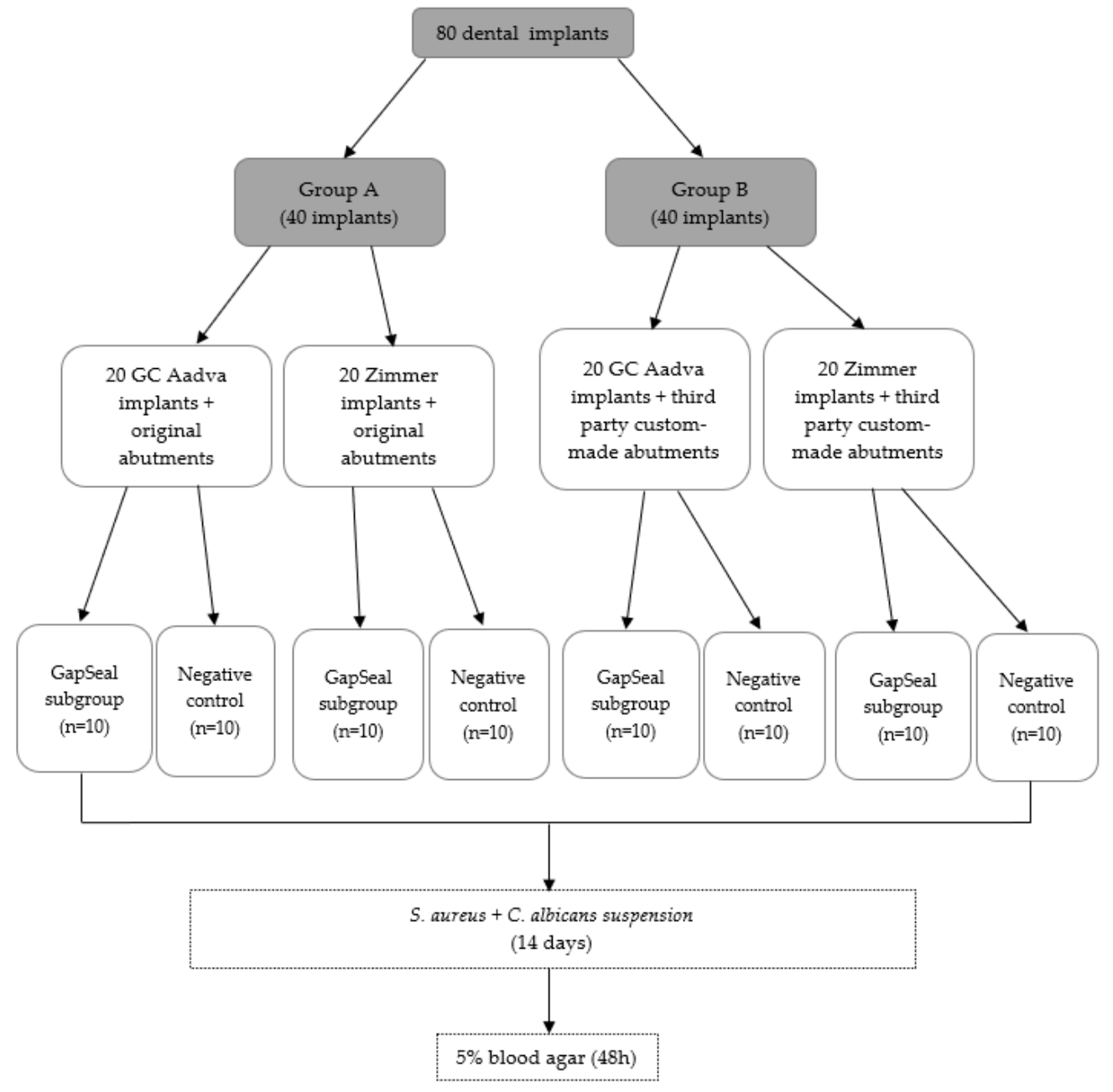

Figure 1. Flow chart illustrating the study design and division of the groups.

\subsection{Preparation of the $I A C$}

Each dental implant and original complementary abutment were removed from their commercial sterile packaging. Custom-made third-party abutments were sterilized in Euroklav 23 VS+ (Melag, Berlin, Germany) before use. All dental implants were placed in a strictly vertical position in a sterile stainless-steel clamp using sterile stainless-steel forceps (Henry Schein, Melville, NY, USA). Then, they were fixed in the clamp that allowed for a firm swivel action when tightening the prosthetic abutment to the values recommended by the respective manufacturer $(20 \mathrm{~N} / \mathrm{cm}$ for GC Aadva Standard and $30 \mathrm{~N} / \mathrm{cm}$ for Zimmer Tapered Screw-Vent implants). The clamp also kept the implants in the desired vertical position (Figure 2). 


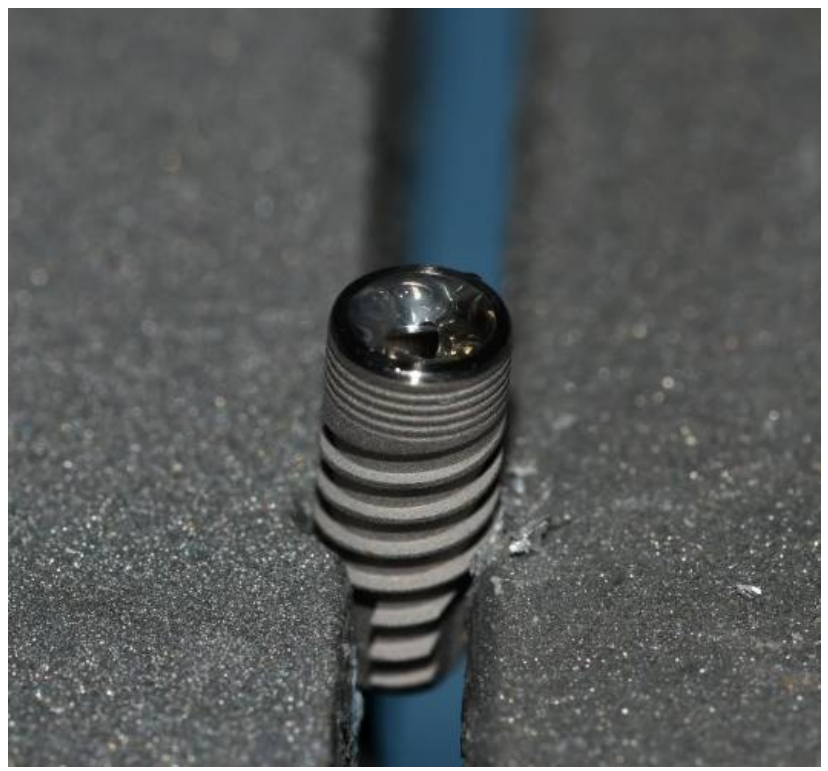

Figure 2. Dental implant fixed in a sterile stainless-steel clamp.

Preceding the installation of the prosthetic abutment, a sterile micropipette (Merck $\mathrm{KGaA}$, Darmstadt, Germany) was used to add $0.3 \mu \mathrm{L}$ of sterile brain heart infusion (BHI) broth (calf brains (12.5 g/L), beef heart infusion solids (5.0 g/L), D-glucose $(2.0 \mathrm{~g} / \mathrm{L})$, proteose peptone $(10.0 \mathrm{~g} / \mathrm{L})$, disodium hydrogen phosphate $(2.5 \mathrm{~g} / \mathrm{L})$ and sodium chloride $(5.0 \mathrm{~g} / \mathrm{L})$ at a $\mathrm{pH} 7.4 \pm 0.2$ and $25^{\circ} \mathrm{C}$ to the implants as a non-selective nutrient media in case of bacterial and fungal penetration. GapSeal (Hager and Werken, Duisburg, Germany) was applied to the internal surface of the implants (Figure 3) in the tested subgroups, while the negative control subgroups did not receive the treatment with sealing material. Regardless of sealant use, prosthetic abutments were installed according to the manufacturer's recommendation (Figure 4).

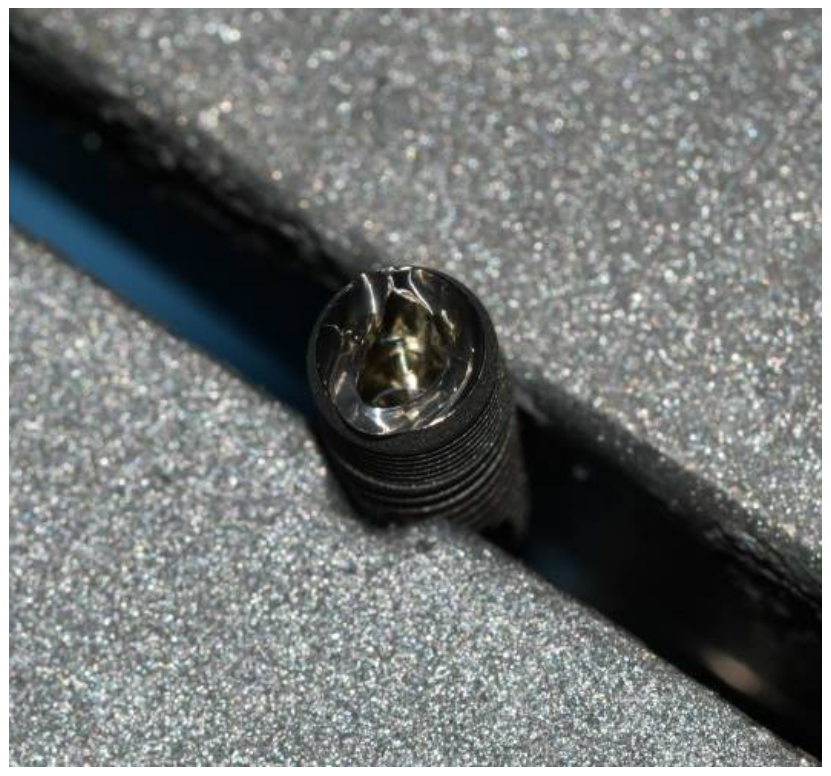

Figure 3. GapSeal gel applied on the implant. 


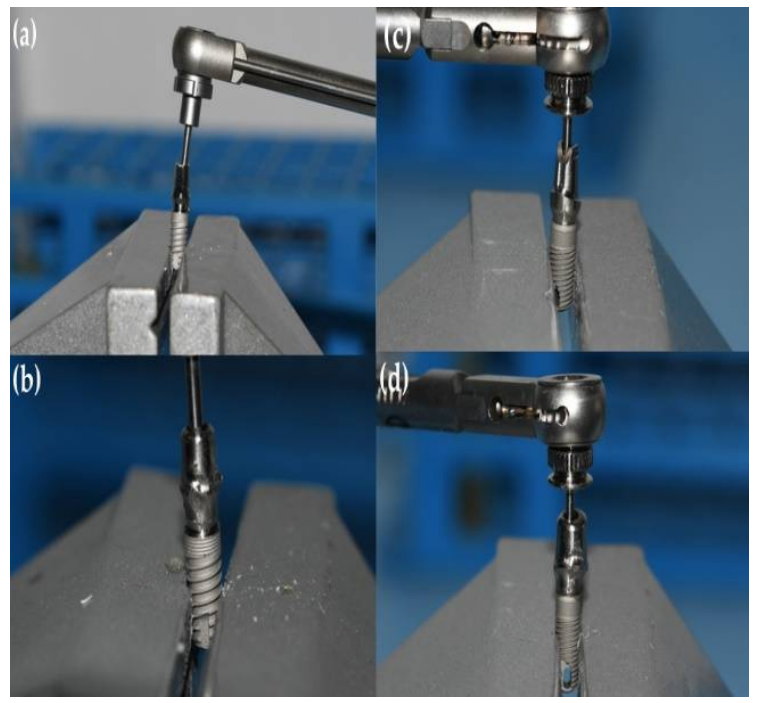

Figure 4. Tightening of the prosthetic abutment. (a) GC Aadva Standard implant with original abutment; (b) GC Aadva implant with third-party custom-made abutment; (c) Zimmer Tapered Screw-Vent implant with original abutment; and (d) Zimmer Tapered Screw-Vent implant with third-party custom-made abutment.

\subsection{Contamination of Implant-Abutment Interfaces}

Dental implants were contaminated by Staphylococcus aureus and Candida albicans strains isolated from a clinical sample at Clinical Hospital Centre Zagreb. Firstly, bacterial and fungal strains had been grown separately in Columbia Agar for $72 \mathrm{~h}$ following the preparation of separated bacterial and fungal suspensions using thioglycolate broth. They were then mixed together in a joint suspension. An optical densitometer (Densimat, Biomerieux, Marcyl'Etoile, France) was used to set a density of $600 \mathrm{~nm}$, which is equivalent to $1 \times 10^{8}$ colony forming units per milliliter $(\mathrm{CFU} / \mathrm{mL})$. All dental implants with installed prosthetic abutments (implant-abutments assemblies) were immersed in $300 \mu \mathrm{L}$ of mixed bacterial and fungal joint suspension for 14 days under aerobic conditions with an incubation temperature of $35^{\circ} \mathrm{C}$ (Figure 5). The suspension contained S. aureus and C. albicans at a density of $0.5 \mathrm{McFarland}$.

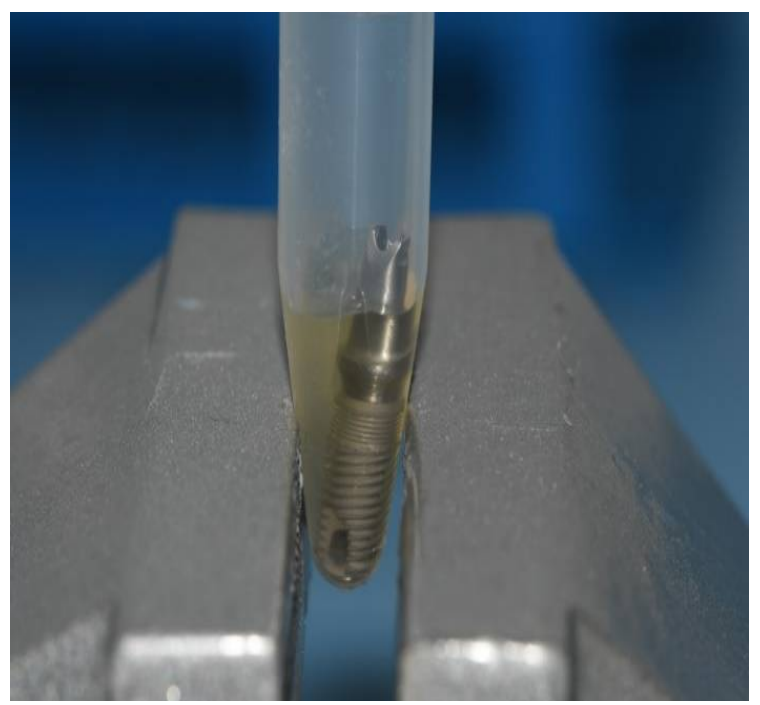

Figure 5. Implant-abutment assembly immersed in bacterial and fungal joint suspension. 
The abutment screw access hole remained above the level of the suspension to eliminate the impact of the penetration of the contaminated suspension along the fixation screw itself.

The implant-abutment assemblies were removed from Eppendorf tubes after 14 days using sterile forceps, following immersion in $70 \%$ ethanol for up to $3 \mathrm{~min}$ to prevent external contamination. Then, the samples were dried with sterile gauze and put in a sterile clamp. They were carefully disassembled in a strictly vertical position. After the abutments were removed, samples were taken from the internal surfaces of the implants using three sterile paper points (Absorbent points, DENTSPLY Maillefer, Tulsa, OK, USA) (Figure 6), which were then immersed in the Eppendorf tubes containing $0.5 \mathrm{~mL}$ of sterile phosphate buffered saline (PBS) solution. The tubes with paper points were inserted into a vortex mixer (Corning ${ }^{\circledR}$ LSE $^{\mathrm{TM}}$ vortex mixer, Corning, NY, USA) for $60 \mathrm{~s}$ to extract bacterial and fungal cells (Figure 7).

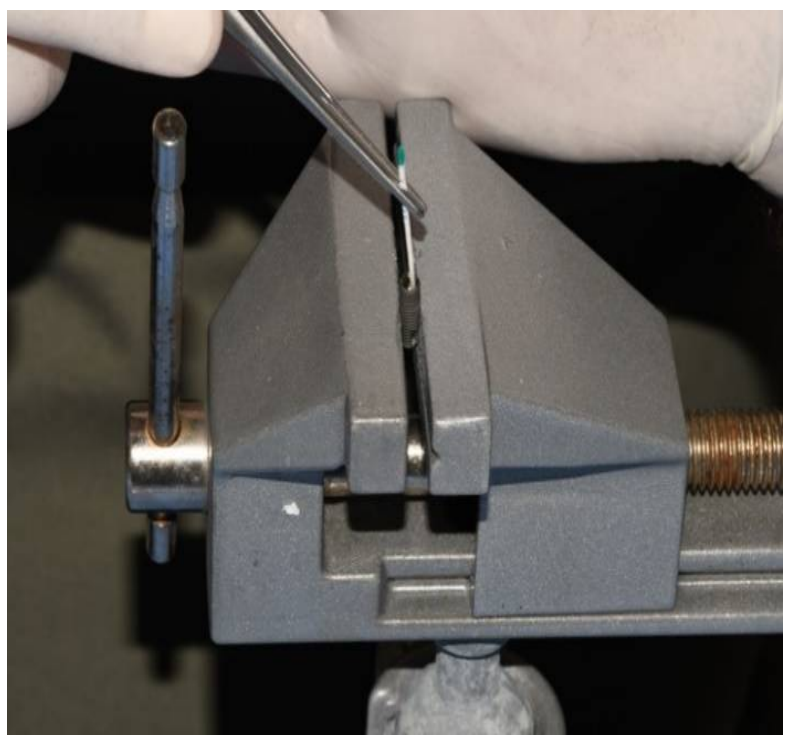

Figure 6. Sampling the implants with paper points.

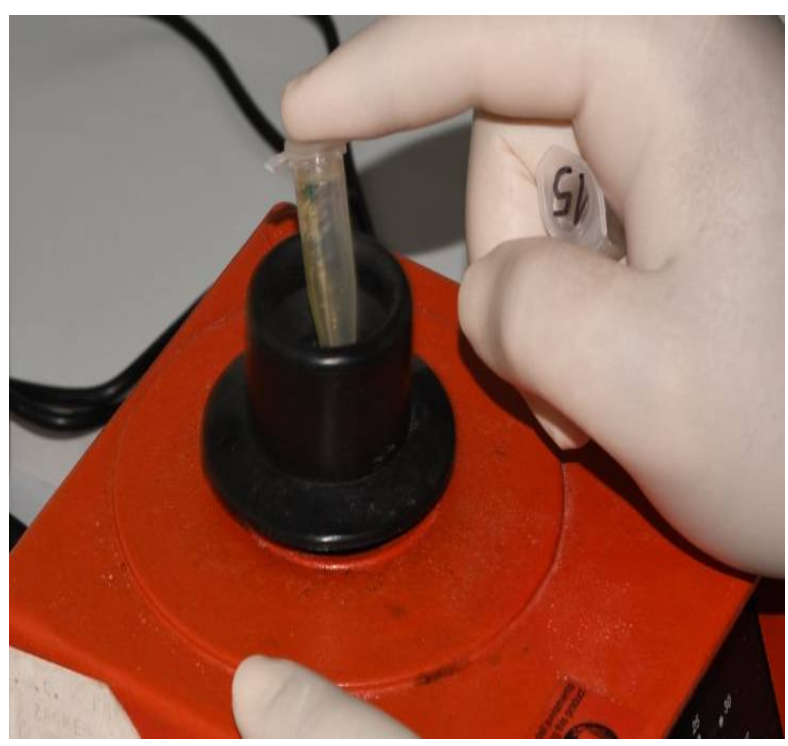

Figure 7. Vortexing. 
Samples of the tube contents were applied on to $5 \%$ blood agar and incubated for $48 \mathrm{~h}$ at $37^{\circ} \mathrm{C}$ (Figure 8). The resulting colonies were then identified, and quantification was performed. For each sample, the CFU/mL was counted. A MALDI Biotyper (Bruker Daltonics, Hamburg, Germany) was used to verify macroscopically distinctive colonies (Figure 9), and the obtained results underwent further analysis.

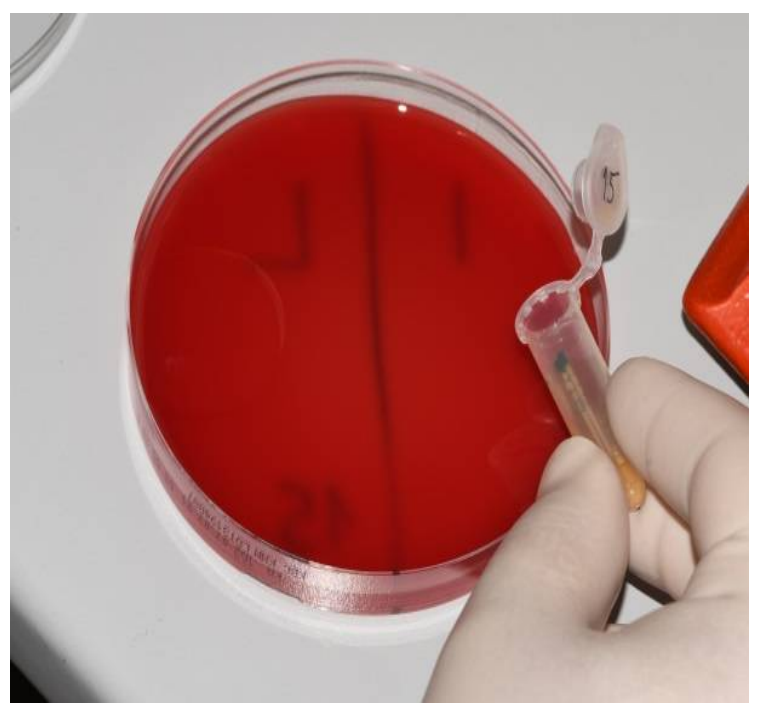

Figure 8. Application of the sample on to $5 \%$ blood agar.

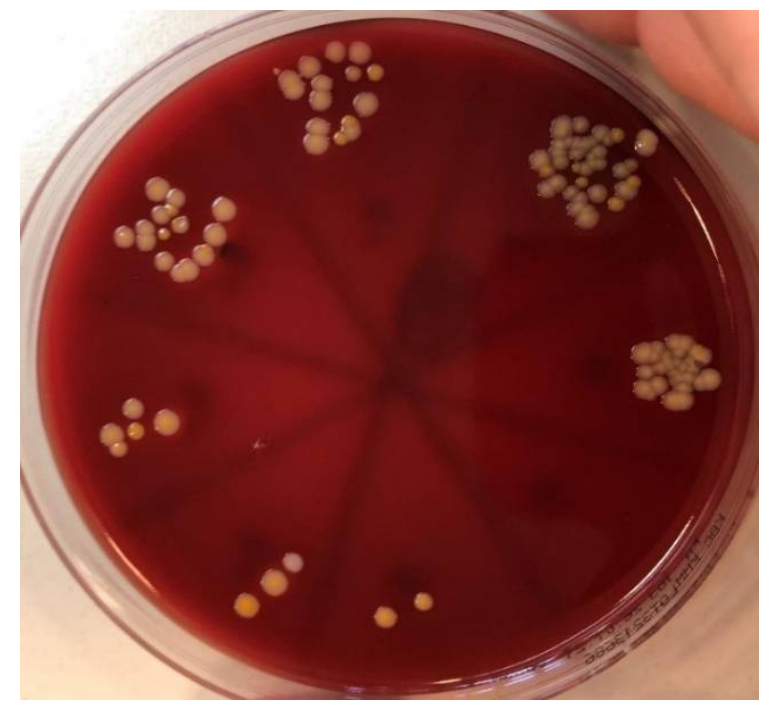

Figure 9. Colonies of Staphylococcus aureus and Candida albicans on 5\% blood agar.

\subsection{Statistical Analysis}

Statistical analysis was performed using Fischer's exact test, with the traditional level of statistical significance set at $p<0.05$. Statistical calculation was performed using MedCalc software version 20.014 (Ostend, Belgium).

\section{Results}

The results were determined based on a frequency of bacterial or fungal microleakage. The presence of $S$. aureus or C. albicans signifies a positive result, and complete absence of these bacteria signified a negative result.

According to the frequencies of bacterial and fungal leakage (Tables 1 and 2), the thirdparty custom-made prosthodontic abutments were compared to the original factory-made prosthodontic abutments with regard to infection with Staphylococcus spp. and Candida 
spp. (Table 3) using the $p$-values of Fisher's exact test. The abutment fabrication method had no influence on the internal fit at the IAC regarding microleakage since the $p$-values of Fisher's exact test were greater than the set level of significance $(p>0.05)$, with the lowest $p$-value being 0.4737 (Table 3). Furthermore, there was no statistically significant relationship between the original and third-party abutments with respect to the type of connection, since $p$-values changed by comparable, statistically non-significant amounts in both GC (conical connection) and Zimmer (straight connection) models (Table 3).

Table 1. The frequencies of bacterial and fungal microleakage (Zimmer Tapered Screw-Vent implants).

\begin{tabular}{ccccc}
\hline Microbe & $\begin{array}{c}\text { Original } \\
\text { Abutments [\%] }\end{array}$ & $\begin{array}{c}\text { Third-Party } \\
\text { Custom-Made } \\
\text { Abutments [\%] }\end{array}$ & $\begin{array}{c}\text { Original } \\
\text { Abutments with } \\
\text { GapSeal [\%] }\end{array}$ & $\begin{array}{c}\text { Third-Party } \\
\text { Custom-Made } \\
\text { Abutments with } \\
\text { GapSeal [\%] }\end{array}$ \\
\hline $\begin{array}{c}\text { Staphylococcus } \\
\text { aureus }\end{array}$ & $80.00(8 / 10)$ & $100.00(10 / 10)$ & $50.00(5 / 10)$ & $70.00(7 / 10)$ \\
\hline Candida albicans & $60.00(6 / 10)$ & $80.00(8 / 10)$ & $20.00(2 / 10)$ & $30.00(3 / 10)$ \\
\hline
\end{tabular}

Table 2. The frequencies of bacterial and fungal microleakage (GC Aadva Standard implants).

\begin{tabular}{ccccc}
\hline Microbe & $\begin{array}{c}\text { Original } \\
\text { Abutments [\%] }\end{array}$ & $\begin{array}{c}\text { Third-Party } \\
\text { Custom-Made } \\
\text { Abutments [\%] }\end{array}$ & $\begin{array}{c}\text { Original } \\
\text { Abutments with } \\
\text { GapSeal [\%] }\end{array}$ & $\begin{array}{c}\text { Third-Party } \\
\text { Custom-Made } \\
\text { Abutments with } \\
\text { GapSeal [\%] }\end{array}$ \\
\hline $\begin{array}{c}\text { Staphylococcus } \\
\text { aureus }\end{array}$ & $90.00(9 / 10)$ & $100.00(10 / 10)$ & $60.00(6 / 10)$ & $60.00(6 / 10)$ \\
\hline Candida albicans & $60.00(6 / 10)$ & $80.00(8 / 10)$ & $20.00(2 / 10)$ & $30.00(3 / 10)$ \\
\hline
\end{tabular}

Table 3. Comparison of Fisher's exact test values for microleakage between original and third-party custom-made prosthodontic abutments.

\begin{tabular}{ccccc}
\hline Implant & \multicolumn{2}{c}{ Zimmer } & \multicolumn{2}{c}{ GC } \\
\hline $\begin{array}{c}\text { Fisher Exact } \\
\text { Test }(\boldsymbol{p} \text {-Values) }\end{array}$ & $\begin{array}{c}\text { Staphylococcus } \\
\text { aureus }\end{array}$ & $\begin{array}{c}\text { Candida } \\
\text { albicans }\end{array}$ & $\begin{array}{c}\text { Staphylococcus } \\
\text { aureus }\end{array}$ & $\begin{array}{c}\text { Candida } \\
\text { albicans }\end{array}$ \\
\hline $\begin{array}{c}\text { Original } \\
\text { prosthodontic } \\
\text { abutment }\end{array}$ & $\begin{array}{c}\text { H0 accepted } \\
(0.4737)\end{array}$ & $\begin{array}{c}\text { H0 accepted } \\
(0.6285)\end{array}$ & $\begin{array}{c}\text { H0 accepted } \\
(0.5000)\end{array}$ & $\begin{array}{c}\text { H0 accepted } \\
(1.0000)\end{array}$ \\
\hline $\begin{array}{c}\text { Third-party } \\
\text { custom-made } \\
\text { prosthodontic } \\
\text { abutment }\end{array}$ & $\begin{array}{c}\text { H0 accepted } \\
(0.6499)\end{array}$ & $\begin{array}{c}\text { H0 accepted } \\
(1.0000)\end{array}$ & $\begin{array}{c}\text { H0 accepted } \\
(0.6285)\end{array}$ & $\begin{array}{c}\text { H0 accepted } \\
(1.0000)\end{array}$ \\
\hline *Statistically significant $(p<0.05) .{ }^{* *}$ Null hypothesis: the abutment fabrication method would have no influence
\end{tabular}
on the internal fit at the IAC, regardless of the connection type and use of a sealing agent.

There was no statistically significant relationship between the original and third-party abutments regarding microleakage when gap sealing material was used (Table 4). Data in Table 4 suggest there was more of an impact with sealing material usage in GC implants when compared with Zimmer implants ( $p=0.0867$ for Staphylococcus aureus in GC and $p=0.2105$ in Zimmer implants), although it was not statistically significant.

Table 5 shows the mean counts of $S$. aureus and C. albicans and the influence of different types of connections, abutments, and usage of sealing material on the amount of leaked microbiota. The microbial counts from Table 5 are separately presented in column charts for both GC and Zimmer implants (Figures 10-13). There were no significant differences in leaked counts between different types of connections, abutments and with or without sealing material. 
Table 4. Comparison of Fisher's exact test values for microleakage with and without application of sealing material (GapSeal).

\begin{tabular}{ccccc}
\hline Implant & \multicolumn{2}{c}{ Zimmer } & \multicolumn{2}{c}{ GC } \\
\hline $\begin{array}{c}\text { Fisher Exact } \\
\text { Test }(p \text {-Values) }\end{array}$ & $\begin{array}{c}\text { Staphylococcus } \\
\text { aureus }\end{array}$ & $\begin{array}{c}\text { Candida } \\
\text { albicans }\end{array}$ & $\begin{array}{c}\text { Staphylococcus } \\
\text { aureus }\end{array}$ & $\begin{array}{c}\text { Candida } \\
\text { albicans }\end{array}$ \\
\hline $\begin{array}{c}\text { Without sealing } \\
\text { material }\end{array}$ & 0.3498 & 0.1698 & 0.3034 & 0.1698 \\
\hline $\begin{array}{c}\text { With sealing } \\
\text { material }\end{array}$ & 0.2105 & 0.0698 & 0.0867 & 0.0698 \\
* Statistically significant $(p<0.05)$. & & &
\end{tabular}

Table 5. Mean counts of Staphylococcus aureus and Candida albicans detected on the internal surface of the implants depending on the abutment fabrication method (original and third-party) and the need for the use of the gap sealing material.

\begin{tabular}{ccc}
\hline & Staphylococcus aureus & Candida albicans \\
\hline Zimmer & CFU/mL mean +/- SD (median) & CFU/mL mean +/- SD (median) \\
\hline Negative control original abut. & $11.2+/-7.9(11)$ & $1.3+/-1.34(1,5)$ \\
\hline Negative control third-party abut. & $76+/-24.59(80)$ & $6.2+/-3.82(6)$ \\
\hline GapSeal original abut. & $5.8+/-6.89(4)$ & $0.3+/-0.67(0)$ \\
\hline GapSeal third-party abut. & $32+/-25.3(40)$ & $2.8+/-4.54(0)$ \\
\hline GC Aadva & CFU/mL mean $+/-$ SD (median) & CFU/mL mean +/- SD (median) \\
\hline Negative control original abut. & $15.2+/-6.68(18)$ & $1.5+/-1.58(1.5)$ \\
\hline Negative control third-party abut. & $66+/-25.03(60)$ & $8.6+/-5.08(10)$ \\
\hline GapSeal original abut. & $8+/-7.89(10)$ & $0.3+/-0.67(0)$ \\
\hline GapSeal third-party abut. & $46+/-44.27(50)$ & $2.2+/-3.82(0)$ \\
\hline
\end{tabular}

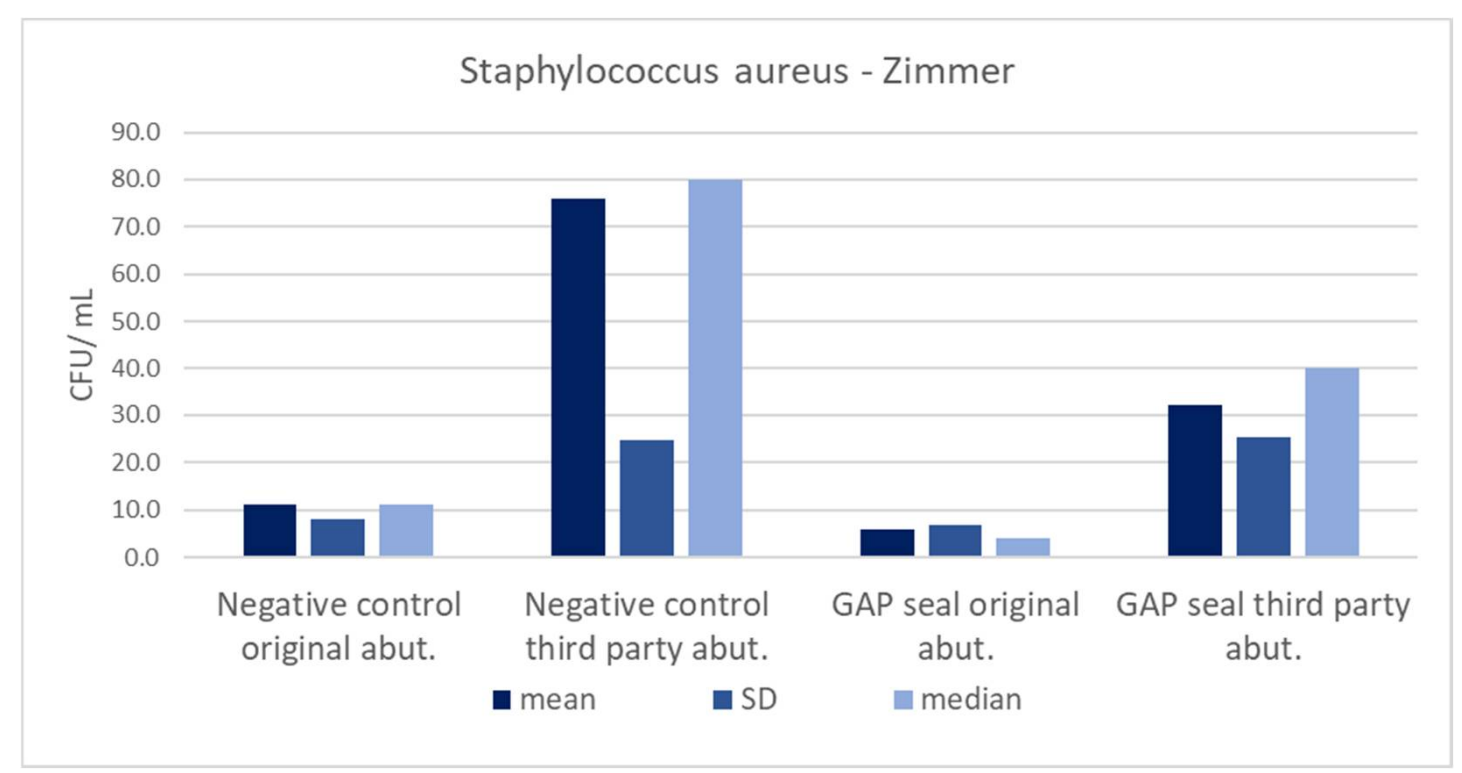

Figure 10. Mean counts of Staphylococcus aureus detected on the internal surface of Zimmer implants depending on the abutment fabrication method (original and third-party) and the need for the use of the gap sealing material. 


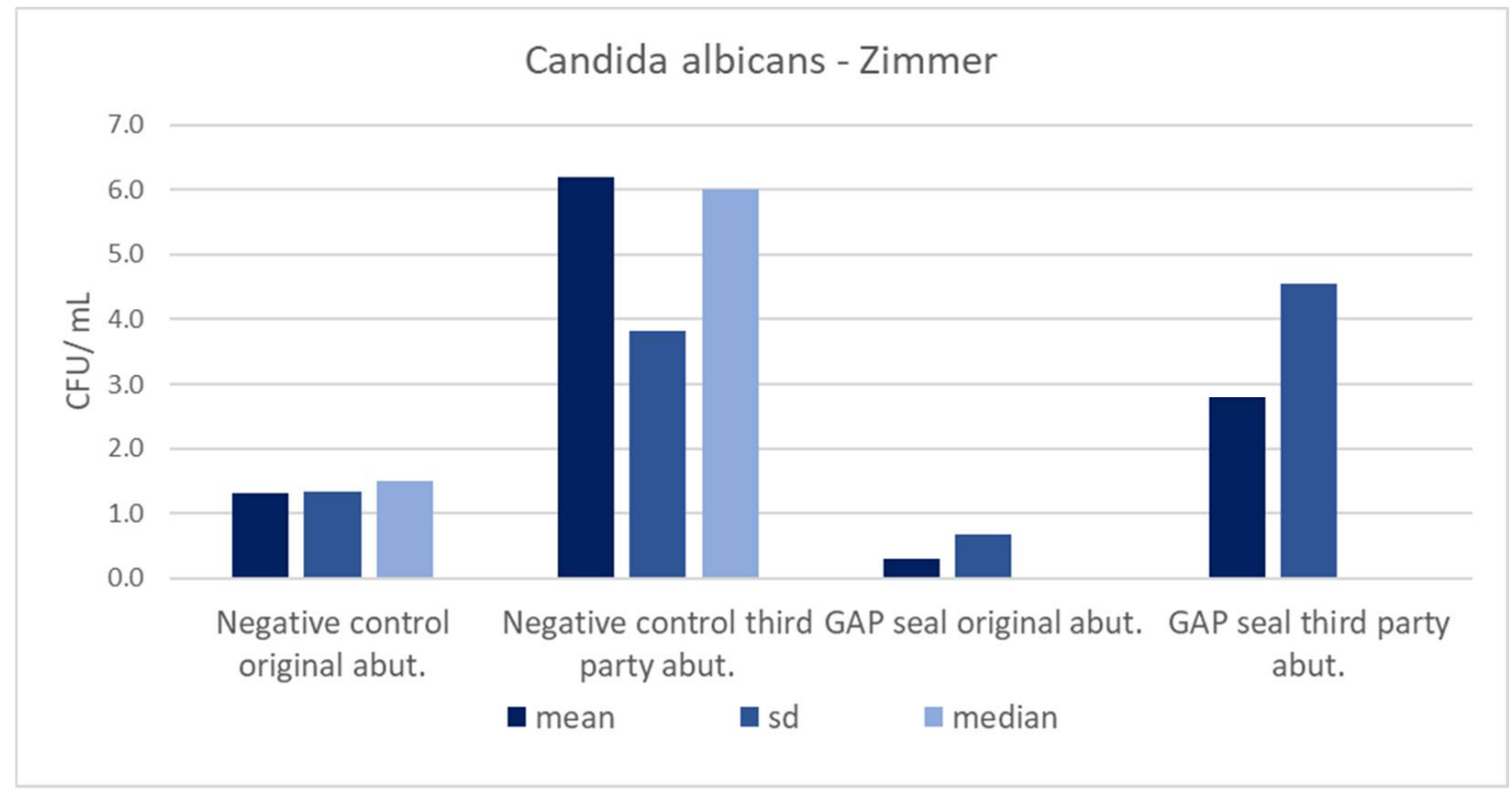

Figure 11. Mean counts of Candida albicans detected on the internal surface of Zimmer implants depending on the abutment fabrication method (original and third-party) and the need for the use of the gap sealing material.

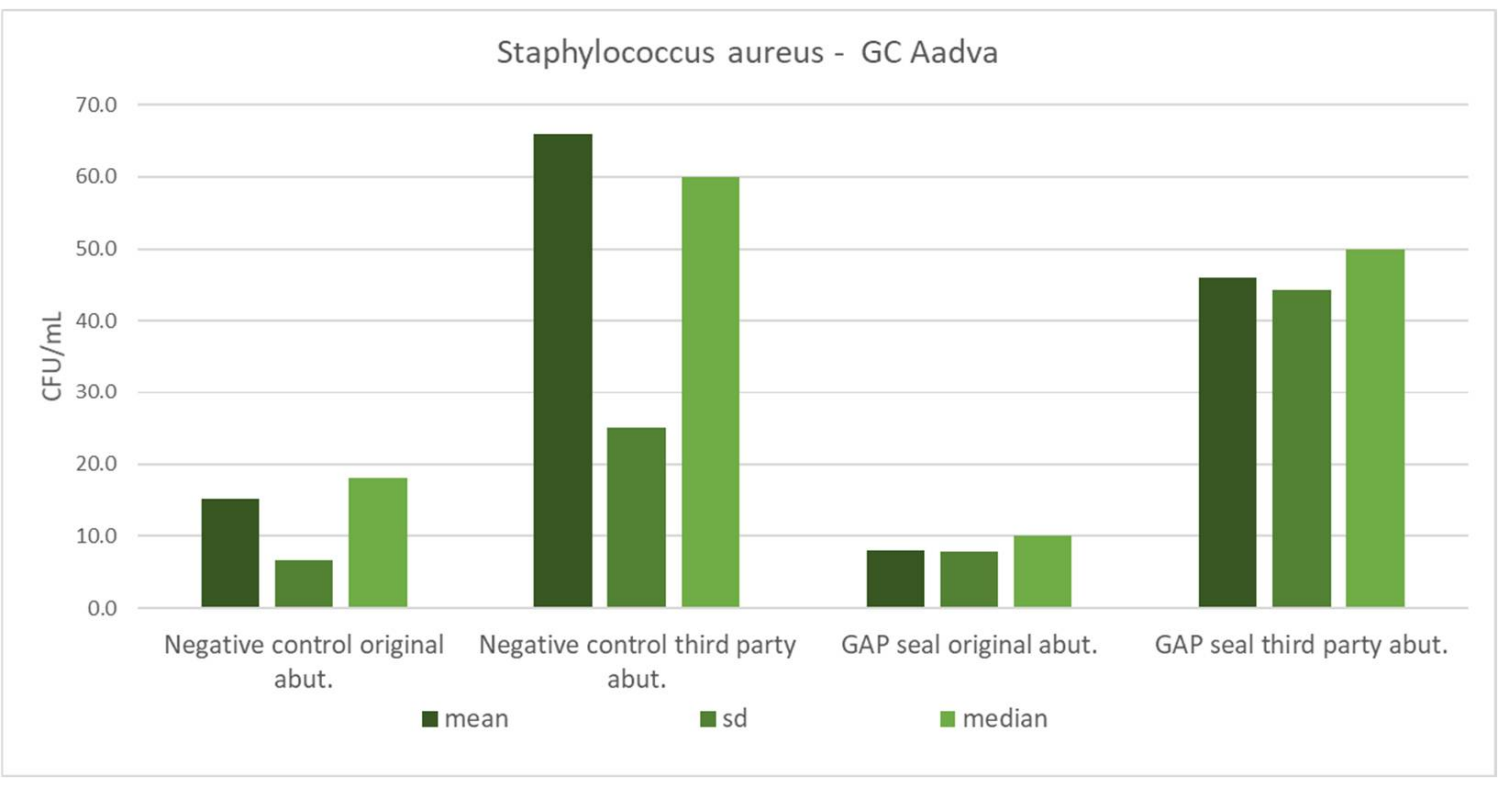

Figure 12. Mean counts of Staphylococcus aureus detected on the internal surface of GC implants depending on the abutment fabrication method (original and third-party) and the need for the use of the gap sealing material. 


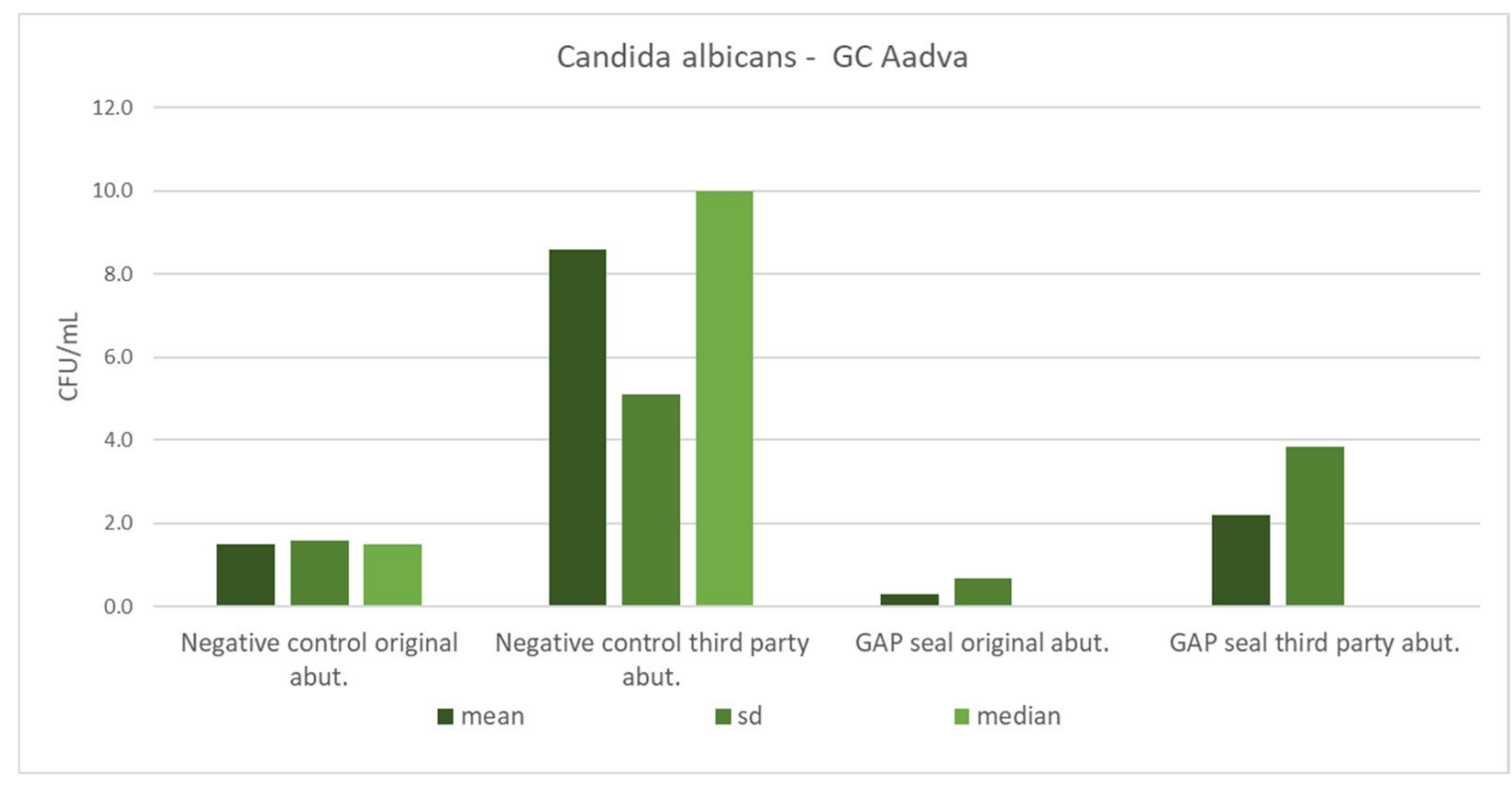

Figure 13. Mean counts of Candida albicans detected on the internal surface of GC implants depending on the abutment fabrication method (original and third-party) and the need for the use of the gap sealing material.

\section{Discussion}

The presented in vitro study tested and compared the gaps of the straight and conical IACs depending on the abutment fabrication method based on bacterial and fungal leakage in static conditions, as well as the antimicrobial efficacy of the sealing material. The null hypothesis was accepted, with findings that the prosthodontic abutment fabrication method was not crucial for successful implant-prosthodontic therapy regarding microbial leakage at the IAC in static conditions. Understanding the pathogenesis of peri-implant diseases, the fabrication method of prosthodontic abutments, and the biomechanical role of IAC is of utmost importance in achieving successful clinical results in implant-prosthodontic therapy.

Considering the finding that bacterial composition of the biofilm formed on dental implants closely resembles that of the neighboring teeth, a switch from peri-implant health to peri-implant mucositis is therefore comparable to gingivitis in terms of bacterial flora [11]. The same postulate is applied in transition to peri-implantitis, which is accompanied by anaerobic species that are commonly found in periodontitis [12]. The biofilm formed around the dental implants is initially dominated by Gram-positive cocci, but eventually shifts to Gram-negative anaerobic and facultatively anaerobic bacteria, such as Aggregaticabacter actinomycetemcomitans, Porphyromonas gingivalis, Prevotella intermedia and Fusobacterium nucleatum [13]. Moreover, it was observed that peri-implantitis is often associated with opportunistic pathogens (Staphylococcus spp.) and fungal organisms (Candida spp.) [14]. Significantly higher counts of S. aureus and S. anaerobius were detected in implants with peri-implantitis when compared to those of healthy implants [15]. The oral microbiome has more than 100 fungal species, and C. albicans plays an important role in the formation and stabilization of biofilm, consequently enabling the development of peri-implant mucositis and peri-implantitis [16]. In addition, C. albicans and S. aureus are rarely associated with periodontal disease, but possess the ability to attach themselves to titanium surfaces [17]. Taking these findings into consideration, it was decided that dental implants in this study would be contaminated with S. aureus and C. albicans, as they are the most important microorganisms that cause inflammation of the soft and hard tissues around dental implants.

Although the differences in microbial leakage between the original and non-original third-party prosthodontic abutments were not statistically significant, non-original thirdparty abutments showed a more frequent prevalence of infection through the IAC. This 
result is in accordance with findings from a study by Alonso-Pérez et al. [18]. They concluded that laser-sintered non-original abutment gaps were within the clinically acceptable range of discrepancy. On the other hand, the same authors, in another study, found that original abutments were highly superior to non-original certified abutments in dynamic conditions, but no statistically significant differences were found in static load behavior [19]. It was also observed that the use of non-original abutment components with original Astra Tech implants showed significant leakage at the IAC in static conditions when compared to the use of original prosthetic abutments from same manufacturer [20]. Since the aforementioned study was also performed in static conditions, it is important to highlight that the results were contrary to the results of this study. From a recent systematic review of in vitro studies by Tallarico et al. [8], it was concluded that the original abutments were superior in terms of marginal accuracy, mechanical outcomes and microleakage in the majority of included studies. Nevertheless, they pointed out that in vitro studies had a high risk of bias, and the outcomes reported in these systematic reviews should be carefully interpreted. According to some authors [21,22], abutment screw closing torque can influence the increased microleakage, and the severity of leakage has an inverse correlation with closing torque. Thus, it is of utmost importance to install the prosthetic abutment to the manufacturer's recommendation. In daily clinical practice, non-original abutments are often selected for financial reasons. Higher leakage values and possible negative mechanical outcomes could be related to many issues that do not allow for exact replication of components, resulting in discrepancies in the dimensions, shape, and design of connecting surfaces. These micromovements at the IAC cause a pumping effect that transports microorganisms from the exterior to the interior surface of the implant and vice versa, creating a vicious circle that results in ongoing infection. In addition to biological issues, further transition of forces from IAC to the implant itself increases the stress on marginal bone level [20]. Precision level and quality control of materials during the manufacturing process are other important factors that must be considered [8].

Further analysis of the results of this study showed that the use of sealing material did not make a statistically significant difference in microleakage at the implant-abutment interface compared to those without sealant. However, GapSeal reduced the amount of leaked microbiota, especially in combination with GC Aadva Standard implants. These improvements were not statistically significant, but gave valuable insights for further studies. A complete hermetic seal at the IAC is not achievable, according to the contemporary literature $[9,23,24]$. The difference between original and third-party abutments regarding microleakage when sealing material is used is inevitably related to internal fit at the IAC. Therefore, it is precisely the marginal accuracy and appropriate design of non-original abutments that play vital roles in the elimination of microleakage. Smojver et al. [9] and Biscoping et al. [25] confirmed that the presence of the sealing agent may be useful in reducing microbial infiltration into the implants. It was concluded that the application of sealing material before abutment connection may reduce the bacterial and fungal populations of the peri-implant, but a complete seal against bacterial infection was not formed at the implant-abutment interface when using different sealing materials (GapSeal, Oxysafe and Flow.sil) [9]. Biscoping et al. [25] found that the tested sealing materials (Clorhexamed $1 \%$ gel and Berutemp) did not influence the gap at the IAC, but the same materials also decreased the torque necessary for loosening the abutment screws. This finding suggests that sealing agents might contribute to negative mechanical outcomes affecting the reverse torque values. Seloto et al. [26] observed that sealing gel (Loctite 2400) promoted lower vertical misfit values at the IAC and preload maintenance of screw-retained prostheses after mechanical cycling. Furthermore, Yu et al. [27] concluded that the GapSeal material reduced microleakage at the IAC after dynamic loading and reported evident abutment screw thread wear protection in three different implant systems with internal conical connection. It is important to emphasize that dynamic conditions in which that study was conducted contributed to different outcomes and plausible major advantages of sealing material usage when compared to those in static conditions. 
Additionally, the presented results did not show a statistically significant difference between original and third-party abutments regarding the type of connection. There is a lack of studies that compare these two types of abutments and the influence of connection type on microleakage at the same time. Considering the type of connection alone, there are various studies observing the connection type with minimal microleakage. De Sousa et al. [28] observed that the external hexagonal connection was more effective than the Morse Taper connection against microbial infiltration for dual species biofilms. Conversely, Quirynen et al. [29] described that connections with an external six-fold design were more prone to microbial invasion. There is also evidence that implants with an internal hexagonal connection are more resistant to bacterial leakage under dynamic loading [30]. The superiority of a conical connection regarding seal performance, gap formation and mechanical stability has also been demonstrated in the literature due to the homogeneous spread of the load [31]. Therefore, the aforementioned studies support the results of this study and, although there was no statistically significant difference between a conical connection and straight connection, GC Aadva implants with a conical connection had slightly better results in combination with sealing material regarding microleakage.

Within the limitations of this in vitro study, primarily a static testing condition and sample size, interesting scientific results were found. However, a larger sample size is needed in future studies, considering the high standard deviation values in the results, and further extensive clinical research should be conducted to assess the outcomes of this study.

\section{Conclusions}

According to the presented results, the abutment fabrication method had no significant influence on the sealing efficacy of the IAC regarding the leakage of bacteria and fungi. Considering the discussed limitations of this study, third-party custom-made abutments represent a viable solution from a microbiological point of view. It is not mandatory to use sealing material, since there was no statistically significant difference in microleakage relative to the presence of the sealing material regardless of the type of abutments. These findings gave important evidence to support studies that would provide more clinical evidence about the long-term outcomes of custom-made abutments and their sealing efficacy.

Author Contributions: Conceptualization, D.G. and I.S.; methodology, I.S.; software, A.Ć.; validation, A.B., M.V. and R.B.; formal analysis, A.B.; investigation, I.S.; resources, R.B.; data curation, A.Ć.; writing-original draft preparation, D.G., I.S. and R.B.; writing—review and editing, D.G. and M.V.; visualization, A.Ć.; supervision, D.G. and M.V.; project administration, A.B.; funding acquisition, A.B. and A.Ć. All authors have read and agreed to the published version of the manuscript.

Funding: This research received no external funding.

Institutional Review Board Statement: The study was conducted according to the guidelines of the Declaration of Helsinki and approved by the Institutional Review Board (or Ethics Committee) of the School of Dental Medicine, University of Zagreb (05-PA-30-XII-12/2019 on 5 December 2019).

Informed Consent Statement: Not applicable.

Data Availability Statement: The data presented in this study are available on request from the corresponding author.

Conflicts of Interest: The authors declare no conflict of interest.

\section{References}

1. Hong, D.G.K.; Oh, J. Recent Advances in Dental Implants. Maxillofac. Plast. Reconstr. Surg. 2017, 39, 33. [CrossRef] [PubMed]

2. Koutouzis, T. Implant-Abutment Connection as Contributing Factor to Peri-Implant Diseases. Periodontol. 2000 2019, 81, 152-166. [CrossRef] [PubMed]

3. Vetromilla, B.M.; Brondani, L.P.; Pereira-Cenci, T.; Bergoli, C.D. Influence of Different Implant-Abutment Connection Designs on the Mechanical and Biological Behavior of Single-Tooth Implants in the Maxillary Esthetic Zone: A Systematic Review. J. Prosthet. Dent. 2019, 121, 398-403.e3. [CrossRef] [PubMed]

4. Lauritano, D.; Moreo, G.; Lucchese, A.; Viganoni, C.; Limongelli, L.; Carinci, F. The Impact of Implant-Abutment Connection on Clinical Outcomes and Microbial Colonization: A Narrative Review. Materials (Basel) 2020, 13, 1131. [CrossRef] 
5. Sinjari, B.; D'Addazio, G.; De Tullio, I.; Traini, T.; Caputi, S. Peri-Implant Bone Resorption during Healing Abutment Placement: The Effect of a $0.20 \%$ Chlorhexidine Gel vs. Placebo-A Randomized Double Blind Controlled Human Study. Biomed. Res. Int. 2018, 2018, 5326340. [CrossRef]

6. D'Ercole, S.; D'Addazio, G.; Di Lodovico, S.; Traini, T.; Di Giulio, M.; Sinjari, B. Porphyromonas Gingivalis Load is Balanced by 0.20\% Chlorhexidine Gel. A Randomized, Double-Blind, Controlled, Microbiological and Immunohistochemical Human Study. J. Clin. Med. 2020, 9, 284. [CrossRef]

7. Carinci, F.; Lauritano, D.; Cura, F.; Lopez, M.A.; Andreasi Bassi, M.; Confalone, L.; Pezzetti, F. Prevention of Bacterial Leakage at Implant-Abutment Connection Level: An in Vitro Study of the Efficacy of Three Different Implant Systems. J. Biol. Regul. Homeost. Agents 2016, 30, 69-73.

8. Tallarico, M.; Fiorellini, J.; Nakajima, Y.; Omori, Y.; Takahisa, I.; Canullo, L. Mechanical Outcomes, Microleakage, and Marginal Accuracy at the Implant-Abutment Interface of Original versus Nonoriginal Implant Abutments: A Systematic Review of In Vitro Studies. Biomed. Res. Int. 2018, 2018, 2958982. [CrossRef]

9. Smojver, I.; Vuletić, M.; Gerbl, D.; Budimir, A.; Sušić, M.; Gabrić, D. Evaluation of Antimicrobial Efficacy and Permeability of Various Sealing Materials at the Implant-Abutment Interface-A Pilot In Vitro Study. Materials 2021, 14, 385. [CrossRef]

10. Hager \& Werken. Available online: https://www.hagerwerken.de/wp-content/uploads/2018/09/GapSeal-GBA-16S-A7-Rev050918-kl-1.pdf (accessed on 5 December 2021).

11. Ito, T.; Mori, G.; Oda, Y.; Hirano, T.; Sasaki, H.; Honma, S.; Furuya, Y.; Yajima, Y. Clinical evaluation of periodontal pathogen levels by real-time polymerase chain reaction in peri-implantitis patients. Int. J. Implant Dent. 2021, 7, 105. [CrossRef]

12. Mombelli, A.; Décaillet, F. The Characteristics of Biofilms in Peri-Implant Disease. J. Clin. Periodontol. 2011, 38, 203-213. [CrossRef] [PubMed]

13. Belibasakis, G.N.; Charalampakis, G.; Bostanci, N.; Stadlinger, B. Peri-Implant Infections of Oral Biofilm Etiology. Adv. Exp. Med. Biol. 2015, 830, 69-84.

14. Albertini, M.; López-Cerero, L.; O’Sullivan, M.G.; Chereguini, C.F.; Ballesta, S.; Ríos, V.; Herrero-Climent, M.; Bullón, P. Assessment of Periodontal and Opportunistic Flora in Patients with Peri-Implantitis. Clin. Oral Implants Res. 2015, 26, 937-941. [CrossRef] [PubMed]

15. Persson, G.R.; Renvert, S. Cluster of Bacteria Associated with Peri-Implantitis. Clin. Implant Dent. Relat. Res. 2014, 16, 783-793. [CrossRef]

16. Smojver, I.; Vuletić, M.; Sušić, M.; Marković, L.; Pelivan, I.; Gabrić, D. The role of Candida species in peri-implant diseases Australas. Med. J. 2020, 13, 98-105. [CrossRef]

17. do Nascimento, C.; Pita, M.S.; Pedrazzi, V.; de Albuquerque, R.F., Jr.; Ribeiro, R.F. In vivo evaluation of Candida spp. adhesion on titanium or zirconia abutment surfaces. Arch. Oral Biol. 2013, 58, 853-861. [CrossRef]

18. Alonso-Pérez, R.; Bartolomé, J.; Ferreiroa, A.; Salido, M.; Pradíes, G. Evaluation of the Mechanical Behavior and Marginal Accuracy of Stock and Laser-Sintered Implant Abutments. Int. J. Prosthodont. 2017, 30, 136-138. [CrossRef] [PubMed]

19. Alonso-Pérez, R.; Bartolomé, J.F.; Ferreiroa, A.; Salido, M.P.; Pradíes, G. Original vs. Non-Original Abutments for Screw-Retained Single Implant Crowns: An in Vitro Evaluation of Internal Fit, Mechanical Behaviour and Screw Loosening. Clin. Oral Implants Res. 2018, 29, 1230-1238. [CrossRef]

20. Berberi, A.; Tehini, G.; Rifai, K.; Bou Nasser Eddine, F.; Badran, B.; Akl, H. Leakage Evaluation of Original and Compatible Implant-Abutment Connections: In Vitro Study Using Rhodamine B. J. Dent. Biomech. 2014, 5, 1-7. [CrossRef]

21. Duarte, A.R.C.; Rossetti, P.H.O.; Rossetti, L.M.N.; Torres, S.A.; Bonachela, W.C. In Vitro Sealing Ability of Two Materials at Five Different Implant-Abutment Surfaces. J. Periodontol. 2006, 77, 1828-1832. [CrossRef]

22. Nayak, A.G.; Fernandes, A.; Kulkarni, R.; Ajantha, G.S.; Lekha, K.; Nadiger, R. Efficacy of Antibacterial Sealing Gel and O-Ring to Prevent Microleakage at the Implant Abutment Interface: An in Vitro Study. J. Oral Implantol. 2014, 40, 11-14. [CrossRef] [PubMed]

23. Mishra, S.K.; Chowdhary, R.; Kumari, S. Microleakage at the Different Implant Abutment Interface: A Systematic Review. J. Clin. Diagn. Res. 2017, 11, 10-15. [CrossRef]

24. Sasada, Y.; Cochran, D. Implant-Abutment Connections: A Review of Biologic Consequences and Peri-implantitis Implications. Int. J. Oral Maxillofac. Implants 2017, 32, 1296-1307. [CrossRef] [PubMed]

25. Biscoping, S.; Ruttmann, E.; Rehmann, P.; Wöstmann, B. Do Sealing Materials Influence Superstructure Attachment in Implants? Int. J. Prosthodont. 2018, 31, 163-165. [CrossRef]

26. Seloto, C.; Strazzi-Sahyon, H.; dos Santos, P.; Assunção, W. Effectiveness of Sealing Gel on Vertical Misfit at the Implant-Abutment Interface and Preload Maintenance of Screw-Retained Implant-Supported Prostheses. Int. J. Oral Maxillofac. Implants 2020, 35 , 479-484. [CrossRef] [PubMed]

27. Yu, P.; Li, Z.; Tan, X.; Yu, H. Effect of Sealing Gel on the Microleakage Resistance and Mechanical Behavior during Dynamic Loading of 3 Implant Systems. J. Prosthet. Dent. 2020, 1-10. [CrossRef]

28. de Sousa, C.A.; Conforte, J.J.; Caiaffa, K.S.; Duque, C.; Assunção, W.G. Sealing Agent Reduces Formation of Single and DualSpecies Biofilms of Candida albicans and Enterococcus faecalis on Screw Joints at the Abutment/Implant Interface. PLoS ONE 2019, $14, \mathrm{e} 0223148$ 
29. Quirynen, M.; van Steenberghe, D. Bacterial Colonization of the Internal Part of Two-stage Implants. An in Vivo Study. Clin. Oral Implants Res. 1993, 4, 158-161. [CrossRef] [PubMed]

30. Steinebrunner, L.; Wolfart, S.; Bössmann, K.; Kern, M. In Vitro Evaluation of Bacterial Leakage along the Implant-Abutment Interface of Different Implant Systems. Int. J. Oral Maxillofac. Implants 2005, 20, 875-881.

31. Ceruso, F. Implant-Abutment Connections on Single Crowns: A Systematic Review. Oral Implantol. 2017, 10, 349-353. [CrossRef] [PubMed] 